\title{
Analisis Kesiapan Belajar Anak di TK Islami An-Nur Bastari Kecamatan Tampan Kota Pekanbaru Selama Pembelajaran Daring
}

\author{
Ummi Fadhillah $^{1]}$, Ria Novianti ${ }^{2]}$, Yeni Solfiah ${ }^{3]}$, Enda Puspitasari ${ }^{4]}$ \\ Universitas Riau \\ E-mail: ${ }^{1}$ ummifadhillahnst@gmail.com \\ ${ }^{2}$ rianovianti.rasyad@gmail.com \\ 33abildaulaey@yahoo.co.id \\ ${ }^{4}$ enda.puspitasari@gmail.com
}

\begin{abstract}
Abstrak
Kesiapan belajar anak adanya pemberlakuan sistem pembelajaran daring sangatlah penting karena adanya perubahan yang sangat spontan terjadi dari sistem luring menjadi daring. Kesiapan belajar anak usia dini yang kurang akan mempengaruhi proses interaksi dan kegiatan belajar. Sehingga, semakin siap anak dalam belajar akan semakin baik proses pembelajaran yang berlangsung. Tujuan penelitian ini adalah untuk mengetahui kesiapan belajar belajar anak TK Islam An-Nur Bastari Kecamatan Tampan Kota Pekanbaru selama pembelajaran daring. Metode penelitian ini adalah deskriptif kuantitatif yang dilaksanakan di TK Islam An-Nur Bastari Pekanbaru. Populasi dalam penelitian ini adalah 20 orang tua anak TK Islam An-Nur Bastari Pekanbaru dengan teknik pengambilan sampel sensus sehingga semua anggota populasi dijadikan sampel. Penelitian ini menggunakan kuesioner kesiapan belajar anak dengan skala likert. Hasil penelitian ini menunjukkan bahwa kesiapan belajar anak selama pembelajaran daring di TK Islam An-Nur Bastari Kecamatan Tampan Kota Pekanbaru sebanyak 45\% berada pada kategori “sedang". Penelitian ini memberikan rekomendasi kepada orang tua untuk meningkatkan perhatian dan pengawasan serta pendampingan dalam kebutuhan anak khususnya dalam proses belajar mengajar, baik saat pembelajaran daring maupun tidak.
\end{abstract}

Kata kunci: Anak usia dini, Kesiapan belajar anak, Pembelajaran daring

\section{Analysis of Children's Learning Readiness in An-Nur Bastari Islamic Kindergarten Tampan District Pekanbaru City During Online Learning}

\begin{abstract}
The readiness of children's learning through the online learning system is very important due to the spontaneous change from offline to online. Less early childhood learning readiness will affect the interaction process and learning activities. So, the more ready the child is to learn, the better the learning process will be. The purpose of this study was to determine the learning readiness of An-Nur Bastari Islamic Kindergarten children, Tampan District, Pekanbaru City during online learning. This research method is quantitative descriptive which was carried out at the An-Nur Bastari Islamic Kindergarten Pekanbaru. The population in this study were 20 parents of Islamic
\end{abstract}


Kindergarten children An-Nur Bastari Pekanbaru by census sampling technique so that all members of the population were sampled. This study uses a children's learning readiness questionnaire with a Likert scale. The results of this study indicate that $45 \%$ of children's learning readiness during online learning at An-Nur Bastari Islamic Kindergarten, Tampan District, Pekanbaru City is in the "medium" category. This study provides recommendations for parents to increase attention and supervision as well as assistance in the needs of children, especially in the teaching and learning process, whether online or not.

Keywords : Children's Learning Readiness, Early Childhood, Online Learning

\section{PENDAHULUAN}

Pandemi covid-19 terjadi di seluruh dunia disebabkan oleh virus coronavirus disease pada bulan Desember 2019 dan memasuki wilayah Indonesia pada akhir Februari 2020 (Armani, 2020). Strain virus coronavirus disease atau yang biasa disebut dengan covid-19 menyebabkan pemerintah harus melakukan upaya pengendalian hal ini disebabkan virus ini sangat mudah menginfeksi dari manusia ke manusia melalui kontak dan tetesan/droplet. Penyebaran virus dilakukan melalui beberapa tindakan diantaranya himbauan untuk melakukan cuci tangan secara reguler, menghindari kontak langsung dengan siapapun, menggunakan masker, dan melalukan pembatasan skala sosial berskala besar dan physical distancing (Kemenkes, 2020).

Pandemi Covid-19 ditetapkan sebagai musibah berskala internasional yang menyebabkan banyak sektor terdampak akibat penyebarannya yang tinggi. Pemerintah menetapkan social distancing, pembatasan sosial berskala besar dan memberlakukan pembelajaran jarak jauh antara pendidik dan peserta didik, semua kegiatan tatap muka di kelas ditiadakan dan digantikan dengan pembelajaran secara online atau terhubung melalui jaringkan komputer dan internet (daring) sejak bulan Maret 2020 agar menekan menyebaran covid-19. Menurut
Bao, (2020) guru dan pendidik sebagai elemen penting dalam pengajaran diharuskan melakukan migrasi secara masif yang belum pernah terjadi sebelumya dari pendidikan tatap muka tradisional ke pendidikan daring atau pendidikan jarak jauh.

Kementerian Pendidikan dan Kebudayaan Republik Indonesia, (2020) menetapkan kebijakan bahwa pelaksanaan belajar selama di rumah terkait pandemi COVID-19, adapun tujuan dilakukan dilakukannya pembelajaran daring adalah 1) memastikan pemenuhan hak anak untuk mendapatkan layanan pendidikan selama pandemi COVID-19, 2) melindungi warga negara satuan pendidikan dan dampak buruk pandemi COVID-19, 3) mencegah penyebaran dan penularan covid-19 di satuan pendidikan, 4) memastikan pemenuhan dukungan psikososial bagi pendidik, anak dan orang tua/wali. Dari penjelasan mengenai pelaksanaan pembelajaran daring terkait adanya pandemi, berdasarkan poin ke empat, maka perlu adanya kesiapan bagi pendidik, anak dan orang tua/wali dalam melaksanakan prosesnya.

Proses pembelajaran dilakukan melalui jaringan internet antara anak dan guru. Interaksi yang terjadi adalah proses pemberian materi dan tugas yang harus anak lakukan di rumah. Jika setiap guru dan anak mampu melakukannya bersama, maka proses belajar mengajar tetap dapat 
terlaksana dengan baik. Kondisi belajar di rumah akibat pandemi Covid-19, menyebabkan guru benar-benar harus mampu menyajikan pembelajaran dengan menggunakan teknologi atau biasa kita sebut dengan pembelajaran daring. Menurut Slameto (2010) mengungkapkan dalam proses belajar yang berpengaruh bagi tujuan pendidikan yang berlangsung salah satu faktor psikologi yang ada didalamnya adalah kesiapan. Awalnya secara terminologi kesiapan belajar (readiness to learn) dikemukan oleh Jensen seorang profesor dibidang psikologi pendidikan di University of California dalam jurnal Clearinghouse on Early Childhood Education pada tahun 1969 yang memperkenalkan konsep kesiapan belajar bukan hanya dari segi kematangan biologis tetapi juga kondisi mental, emosional dan lingkungan anak dalam praktek pendidikan (Jensen, 1969).

Pembelajaran daring di Indonesia selama pandemi sejauh ini dilaksanakan dengan menggunakan fasilitias google classroom, whatsapp, kelas cerdas, zenius, quipper, ruang guru dan microsoft (Abidah et al, 2020). Namun, dalam beberapa pemberitaan media massa dan elektronik seperti yang ditulis oleh Wijaya (2020) diketahui bahwa ketidakefektifan belajar terjadi sejak pendidikan jarak jauh diterapkan adalah keterbatasan fasilitas pendukung dan ketidaksiapan anak belajar di rumah. Beberapa permasalahan yang sering dikeluhkan oleh orang tua anak adalah: (1) tidak adanya fasilitas smartphone, (2) lesunya perekonomian menyebabkan masyarakat kesulitan untuk membeli kuota internet, (3) jaringan internet yang kurang mendukung di beberapa daerah, (3) orang tua tidak dapat membimbing dan membantu memahami tugas yang diberikan guru, (4) anak-anak usia dini banyak yang tidak dapat mengikuti intruksi orang tua. Selain itu, berdasarkan survei online yang dilakukan oleh Kemen PPPA (2020) di 29 provinsi diketahui bahwa $58 \%$ anak punya perasaan tidak menyenangkan selama belajar di rumah.

Kesiapan belajar anak dengan pemberlakuan pembelajaran online sangatlah penting karena adanya transisi pembelajaran yang face-to-face menjadi sepenuhnya daring (Jamal, 2020). Teori belajar koneksionisme menjelaskan bahwa kesiapan dalam belajar ialah salah satu hukumubelajar. Hukum belajar menjelaskan bahwa setiap anak yang memberikan respon secara tanggap dengan adanya stimuli sehingga anak menjadi siap, namun sebaliknya saat anak tidak memberikan respon stimulus yang ada saat anak tersebut belum siap (Pangestu \& Rohinah, 2018).

Kesiapan belajar adalah segala keadaan yang terjadi pada diri anak yang dapat menjadikannya siap untuk memberi respons melalui sikap/perilaku tertentu dalam menanggapi kondisi tersebut (Slameto, 2010). Apabila kesiapan belajar anak baik maka anak dapat duduk lama di memperhatikan pembelajaran, anak usia dini yang siap belajar juga umumnya dapat memegang alat tulis huruf dengan tujuan anak akan banyak menulis materi dan tugas, dan anak dapat memperhatikan/menyimak ketika guru sedang menyampaikan materi pengajaran agar tujuan pengajaran anak dapat memahami apa yang disampaikan oleh guru dapat tercapai dengan baik.

Berdasarkan surat edaran Kemendikbud No. 15 dan No.4 tahun 2020 tentang Pedoman penyelenggaraan belajar dari rumah dalam masa darurat penyebaran Covid-19, pembelajaran yang dilakukan selama tahun ajaran 2020-2021 adalah melalui daring atau online. Pembelajaran jarak jauh (PJJ) ditetapkan dengan menggunakan berbagai fasilitas 
teknologi yang dibutuhkan untuk menunjang adanya pembelajaran seperti koneksi internet, smartphone atau perangkat komputer. Perubahan proses pembelajaran ini menuntut kesiapan belajar anak.

Kesiapan belajar anak usia dini menurut Thomas (2006) yang mengatakan bahwa anak usia dini (4-6 tahun) umumnya siap belajar apabila komponen sosial, emosional, sikap/perilaku yang tercermin dalam disposisi anak dalam menganggapi proses pembelajaran. Lebih lanjut, penelitian yang dilakukan oleh Fedina et al (2017) menemukan bahwa kesiapan dalam belajar pada pembelajaran jarak jauh juga perlu dilihat dalam aspek pengetahuan pengguna teknologi (anak, orang tua, guru) dalam mengakses teknologi karena kesiapan belajar juga terkait dalam kemampuan operasi teknologi yang digunakan.

Pentingnya kesiapan belajar menurut Slameto (2010) dikarenakan saat kesiapan belajar anak optimal maka anak akan memberi respon dengan kematangan. Semakin baik penyesuaian dan respon yang diberikan anak akan menunjukkan kecenderungan pada kemampuan menyerap informasi. Jika tidak adanya kesiapan atau kesediaan dalam belajar maka proses belejar akan berlangsung kurang efektif. Kesiapan sikap dan emosi anak usia dini ditinjau dari kesiapan emosinal yang ditaksirkan dalam bentuk kewajiban dalam menyelesaikan tugas, dorongan semangat terhadap tugas, kemauan beradaptasi, kenyamanan dan kemandirian dalam menjalankan tugas dan apresiasi nilai dalam suatu tugas. Sedangkan kesiapan kognitif anak ditinjau dari keterampilan berpikir kritis dan pentingnya melakukan tugas, kesadaran pada kekurangan dan kekuatan, sudah membuat hubungan dengan tugas dilakukan dengan kenyataan yang ada, kesadaran akan nilai dan kemampuan menjalankan tugas, dan kemampuan mengintegrasikan konsep atau alat pada pelajaran yang ada. Kesiapan perilaku anak usia dini ditinjau dari kesediaan menjalankan fungsi dengan teman dan orang tua, dan kemahiran anak dalam mengatur waktu untuk mencapai tujuan dalam tugas yang diberikan.

Anak usia dini membutuhkan proses pematangan belajar yang perlu diasah agar anak dapat menikmati pembelajaran, memiliki minat, motivasi, beradaptasi, siap menerima tugas dan tanggung jawab dan dapat berkomunikasi dengan baik. Selanjutnya, Rifai \& Fahmi (2017) kesiapan belajar anak usia dini yang kurang akan mempengaruhi proses interaksi dan kegiatan belajar. Sehingga, semakin siap anak dalam belajar akan semakin baik proses pembelajaran yang berlangsung.

TK Islam An-Nur Bastari Kecamatan Tampan Kota Pekanbaru merupakan salah satu sekolah yang menerapkan pembelajaran daring bagi anak usia dini. Pembelajaran daring yang dilaksanakan di TK umumnya diberikan guru dengan membuat video singkat tentang pembelajaran dan memberikan grup whatsapp kepada orang tua sebagai panduan belajar di rumah. Anak umumnya diberikan tugas-tugas tertentu yang juga akan diunggah ke grup whatsapp untuk melaporkan kegiatan di rumah yang sudah dilakukan.

Berdasarkan wawancara dengan guru di TK Islam An-Nur Bastari Kecamatan Tampan Kota Pekanbaru diketahui bahwa terdapat dampak positif dan negatif dari penerapannya, beberapa siswa terlihat antusias dengan pembelajaran daring dikarenakan merupakan hal baru bagi mereka dan tidak perlu ke sekolah untuk mendapatkan proses pembelajaran, selain itu terdapat 
kendala secara teknis selama proses pembelajaran selama pembelajaran daring, seperti adanya keluhan dari orang tua anak akan sulitnya konektivitas internet, adanya anak yang tidak memberikan respon saat kelas daring diberikan, dan masih ada anak yang mengantuk saat proses pembelajaran daring.

Berbagai permasalahan belajar yang dialami anak secara daring ini dapat menyebabkan berbagai permasalahan lebih lanjut dalam proses pembelajaran khususnya ketidaktercapaian tujuan pembelajaran. Berdasarkan permasalahan yang telah dipaparkan, maka penulis tertarik untuk melakukan penelitian yang berjudul "Analisis Kesiapan Belajar Siswa di TK Islam An-Nur Bastari Kecamatan Tampan Kota Pekanbaru Selama Pembelajaran Daring".

\section{METODE}

Penelitian ini dilakukan di TK Islam An-Nur Bastari Pekanbaru. Penelitian ini berjenis kuantitatif yaitu penelitian yang didasari atas pandangan pemikiran positivisme yang digunakan untuk mentelaah pada sampel dengan menggunakan metode pengumpulan data tertentu serta menggunakan adanya analisis data bersifat statistik (Sugiyono, 2017). Populasi dalam penelitian ini adalah seluruh anak di TK Islam An-Nur Bastari Kecamatan Tampan Kota Pekanbaru dengan jumlah 20 orang tua anak. Sampel dalam penelitian ini diambil dengan teknik sampel jenuh yaitu mengambil seluruh populasi untuk dijadikan sampel. Menurut Arikunto, (2010) apabila populasi < 100 responden maka seluruh populasi dapat langsung dijadikan sampel penelitian. Sehingga sampel dalam penelitian ini adalah 20 anak yang akan dibantu oleh orang tua dalam pengisian instrumen penelitian. Data yang digunakan dalam penelitian ini adalah data primer yaitu data yang diperoleh langsung dari responden yang akan diteliti. Instrumen yang digunakan adalah kuesioner (angket) yang dibagikan kepada orang tua anak dengan instrumen kuisioner.

Kuesioner atau angket tertutup yang dijadikan sebagai instrumen dalam penelitian ini menggunakan pilihan atau alternatif jawaban yang sudah ada, sehingga responden dapat memilih pilihan jawaban yang diberikan pada masingmasing pernyataan. Skala pengukuran yang digunakan adalah Skala Likert dengan 4 alternatif jawaban. Alasan menggunakan 4 alternatif jawaban tersebut untuk menghindari jawaban yang cenderung pada nilai tengah. Skala likert adalah salah satu skala yang digunakan untuk mengukur sikap, pendapat, dan persepsi seseorang atau sekelompok orang tentang suatu fenomena sosial.

Dengan menggunakan Skala Likert, maka variabel yang akan diukur dijabarkan menjadi dimensi, dimensi dijabarkan menjadi sub variabel kemudian sub variabel dijabarkan lagi menjadi indikator-indikator yang dapat diukur. Akhirya indikator-indikator yang terukur ini dapat dijadikan titik tolak untuk membuat item-item instrument yang berupa pertanyaan atau pertanyaan yang perlu dijawab oleh responden. (Riduwan dan Sunarto, 2011). Penyataaan yang disusun sebagai instrumen yang berupa pernyataan positif. Instrumen penelitian ini dari teori kesiapan (readiness) dari Soemanto. Data diperoleh melalui google form yang dilakukan uji validitas dan reliabilitas terlebih dahulu. Data di analisis secara deskriptif untuk mengetahui dan menganalisis data mengenai kesiapan belajar anak. 


\section{Uji Coba Instrumen Penelitian}

Analisis instrumen dilakukan dengan uji validitas dan uji reliabilitas, uji validitas dilakukan untuk menguji kesahihan atau kevalidan suatu instrumen apakah layak dijadikan alat ukur. Hasil pengujan validitas diketahui bahwa item pernyataan nomor 8 dan 21 memiliki $r_{\text {hitung }}<r_{\text {tabel }}$, sehingga item tersebut gugur, sedangkan item lainnya memiliki nilai $\mathrm{r}_{\text {hitung }}$ berkisar antara 0,430 hingga 0,792 yang menandakan bahwa nilai tersebut lebih besar dari $r_{\text {tabel }}$ dan dinyatakan valid. Dengan demikian instrumen kesiapan belajar anak selain nomor 8 dan 21 layak untuk dijadikan alat pengukuran variabel kesiapan belajar anak selama pembelajaran daring di TK Islam An-Nur Bastari Kecamatan Tampan Kota Pekanbaru. Hasil pengujian reliabiltas diperoleh bahwa nilai cronbach's alpha adalah 0,911 yang lebih besar dari 0,70 sehingga instrumen kesiapan belajar anak selama pembelajaran daring dinyatakan reliabel dan layak dijadikan instrumen pengukuran variabel.

Tabel 1. Kisi-kisi instrumen kesiapan belajar anak setelah uji coba

\begin{tabular}{|c|c|c|c|c|}
\hline \multirow{2}{*}{ Indikator } & \multirow{2}{*}{$\begin{array}{c}\text { Sub } \\
\text { Indikator }\end{array}$} & \multicolumn{2}{|c|}{ Nomor butir } & \multirow{2}{*}{ Jumlah } \\
\hline & & Fav & Unfav & \\
\hline $\begin{array}{l}\text { Kesiapan } \\
\text { fisik }\end{array}$ & $\begin{array}{l}\text { Kondisi } \\
\text { berhubungan } \\
\text { dengan indera } \\
\text { pendengaran, } \\
\text { penglihatan } \\
\text { dan } \\
\text { kemampuan } \\
\text { berbicara }\end{array}$ & $1,2,3$ & 20 & 4 \\
\hline $\begin{array}{l}\text { Kondisi } \\
\text { mental }\end{array}$ & $\begin{array}{l}\text { Kemampuan } \\
\text { siswa dalam } \\
\text { mengemukan } \\
\text { pendapat, rasa } \\
\text { percaya diri } \\
\text { terhadap } \\
\text { kemampuan } \\
\text { yang dimiliki }\end{array}$ & 4,5 & 6,7 & 4 \\
\hline $\begin{array}{l}\text { Kondisi } \\
\text { emosional }\end{array}$ & $\begin{array}{l}\text { Kemampuan } \\
\text { siswa } \\
\text { mengatur } \\
\text { emosinya }\end{array}$ & 8 & 9,10 & 3 \\
\hline $\begin{array}{l}\text { Kebutuhan } \\
\text { terhadap } \\
\text { materi } \\
\text { pelajaran } \\
\end{array}$ & $\begin{array}{l}\text { Motif siswa } \\
\text { dalam } \\
\text { mempelajari } \\
\text { matapelajaran }\end{array}$ & $11,12,13$ & 14,15 & 5 \\
\hline
\end{tabular}

\begin{tabular}{|c|c|c|c|c|}
\hline \multirow{2}{*}{ Indikator } & \multirow{2}{*}{$\begin{array}{c}\text { Sub } \\
\text { Indikator }\end{array}$} & \multicolumn{2}{|c|}{ Nomor butir } & \multirow{2}{*}{ Jumlah } \\
\hline & & Fav & Unfav & \\
\hline $\begin{array}{l}\text { Pengetahuan } \\
\text { atau } \\
\text { pemahaman } \\
\text { anak } \\
\text { terhadap } \\
\text { materi } \\
\text { pelajaran }\end{array}$ & $\begin{array}{l}\text { Pemahaman } \\
\text { siswa } \\
\text { mengenai } \\
\text { materi yang } \\
\text { telah diajarkan } \\
\text { atau materi } \\
\text { yang akan } \\
\text { diajarkan }\end{array}$ & 17,18 & 16,19 & 4 \\
\hline \multicolumn{2}{|c|}{ Jumlah soal } & 11 & 9 & 20 \\
\hline
\end{tabular}

\section{HASIL DAN PEMBAHASAN Karakteristik Responden Penelitian}

Data penelitian ini disajikan dengan menggunakan data distribusi frekuensi dan persentase. Hasil mengenai profil orang tua dan anak di TK Islam AnNur Bastari Kecamatan Tampan Kota Pekanbaru akan dikemukakan dalam bentuk deskriptif dengan jumlah orang tua dalam menilai kesiapan belajar anak dalam penelitian ini adalah 20 orang Tabel 2 berikut ini.

Tabel 2. Profil Responden orang tua dan anak di TK Islam An-Nur Bastari Kecamatan Tampan Kota Pekanbaru

\begin{tabular}{|c|c|c|c|c|}
\hline No & $\begin{array}{c}\text { Karakteristik } \\
\text { Responden }\end{array}$ & Kategori & Frekuensi (f) & Persentase $(\%)$ \\
\hline \multirow[t]{6}{*}{1} & \multirow{6}{*}{$\begin{array}{c}\text { Usia Orang } \\
\text { Tua }\end{array}$} & 29 Tahun & 2 & 10 \\
\hline & & 31 Tahun & 2 & 10 \\
\hline & & 32 Tahun & 4 & 20 \\
\hline & & 33 Tahun & 6 & 30 \\
\hline & & 34 Tahun & 4 & 20 \\
\hline & & 35 Tahun & 2 & 10 \\
\hline \multirow[t]{3}{*}{2} & \multirow[t]{3}{*}{ Usia Anak } & 4 Tahun & 9 & 45 \\
\hline & & 5 Tahun & 6 & 30 \\
\hline & & 6 Tahun & 5 & 25 \\
\hline \multirow[t]{4}{*}{3} & \multirow{4}{*}{$\begin{array}{l}\text { Pendidikan } \\
\text { Terakhir } \\
\text { Orang Tua }\end{array}$} & SMA & 5 & 25 \\
\hline & & D3 & 3 & 15 \\
\hline & & $\mathrm{S} 1$ & 11 & 55 \\
\hline & & $\mathrm{S} 2$ & 1 & 5 \\
\hline
\end{tabular}

Sumber: Data olahan, 2020

Berdasarkan Tabel 2 di atas, terdapat 3 kategori profil responden yaitu usia orang tua, usia anak dan pendidikkan terakhir orang tua. Pada kategori usia orang tua terdapat usia 29 hingga 35 tahun. Dari 20 jumlah orang tua yang dinilai kesiapan belajar anaknya selama pembelajaran daring di TK Islam An-Nur Bastari Kecamatan Tampan Kota 
Pekanbaru, sebagian besar berada pada usia 33 tahun sebanyak 6 orang (30\%), sedangkan usia 29 tahun, 31 tahun, dan 35 tahun masing-masing sebanyak 2 orang (10\%), usia 32 tahun dan 34 tahun masing masing sebanyak 4 orang (20\%). Berdasarkan sebaran usia pada anak yaitu 4 hingga 6 tahun. Berdasarkan 20 orang anak yang diteliti, sebagian besar berada pada usia 4 tahun sebanyak 9 anak (45\%), kemudian usia 5 tahun terdapat 6 anak (30\%), dan usia 6 tahun terdapat 5 anak (25\%). Kemudian pada tingkat pendidikan terakhir orang tua, dari 20 jumlah sampel sebagian besar tamatan S1 sebanyak 11 orang tua (55\%), kemudian SMA, D3, dan S2 masing-masing terdapat 3 orang tua $(15 \%)$. Tidak ada orang tua anak yang tidak bersekolah atau tamatan SD hingga SMP.

Sedangkan untuk ketersediaan fasilitas yang dimiliki orang tua selama pembelajaran daring adalah sebagai berikut.

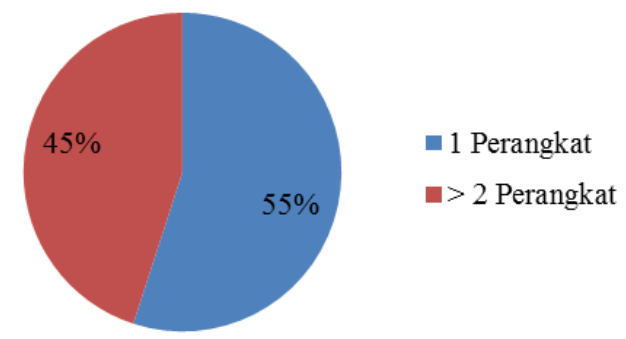

\section{Gambar 1. Ketersediaan perangkat $\mathrm{HP} /$ smartphone selama pembelajaran daring}

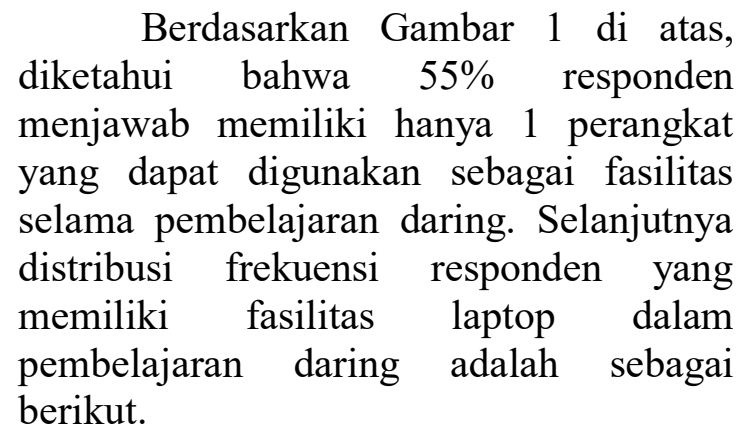

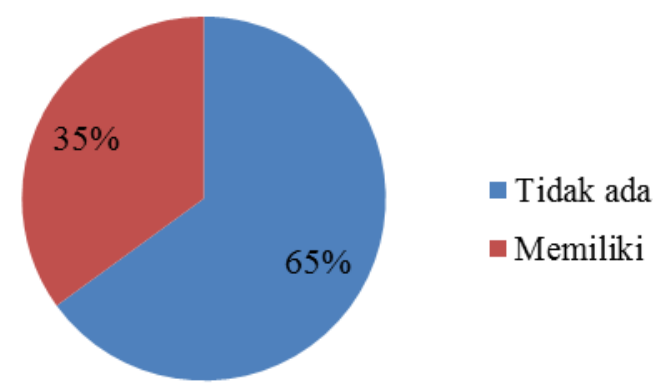

Gambar 2. Ketersediaan perangkat laptop selama pembelajaran daring

Berdasarkan Gambar 2 yang terlihat di atas, dapat diketahui bahwa $65 \%$ responden menjawab tidak memiliki laptop yang dapat digunakan sebagai fasilitas selama pembelajaran daring.

\section{Analisis Kesiapan Belajar Anak Selama Pembelajaran Daring}

Jumlah pernyataan mengenai kesiapan belajar anak selama pembelajaran daring dalam angket yang diberikan kepada orang tua sebagai wali dalam pengisian angket adalah sebanyak 20 butir soal. Berdasarkan jawaban dari angket masing-masing orang tua yang menjadi responden dalam penelitian mengenai kesiapan belajar anak selama pembelajaran daring di TK Islam An-Nur Bastari Kecamatan Tampan Kota Pekanbaru didapatkan gambaran pada Tabel 3 berikut ini. 
Tabel 3. Distribusi frekuensi kesiapan belajar anak selama pembelajaran daring di TK Islam An-Nur Bastari Kecamatan Tampan Kota Pekanbaru

\begin{tabular}{|c|c|c|c|c|c|}
\hline No & Klasifikasi & Kategori & Frekuensi & $\begin{array}{c}\text { Persentase } \\
(\%)\end{array}$ & Mean \\
\hline 1 & $69-80$ & $\begin{array}{l}\text { Sangat } \\
\text { Tinggi }\end{array}$ & 0 & 2 & 46,45 \\
\hline 2 & $57-68$ & Tinggi & 2 & 10 & \\
\hline 3 & $45-56$ & Sedang & 9 & 45 & \\
\hline 4 & $33-44$ & Rendah & 7 & 35 & \\
\hline 5 & $20-32$ & $\begin{array}{l}\text { Sangat } \\
\text { Rendah }\end{array}$ & 2 & 10 & \\
\hline & Total & & 20 & 100 & \\
\hline
\end{tabular}

Sumber: Data olahan, 2020

Berdasarkan Tabel 3 yang tersaji di atas, dapat dinyatakan bahwa secara umum kesiapan belajar anak selama pembelajaran daring di TK Islam An-Nur Bastari Kecamatan Tampan Kota Pekanbaru tergolong sedang. Secara lebih rinci variabel kesiapan belajar anak selama pembelajaran daring dibagi dalam lima indikator yaitu kesiapan fisik, kondidi mental, emosional, kebutuhan terhadap materi pelajaran dan pengetahuan atau pemahaman anak terhadap materi. Analisis deskriptif persentase untuk masing-masing indikator dari variabel kesiapan belajar anak selama pembelajaran daring adalah sebagai berikut.

\section{a. Kesiapan fisik}

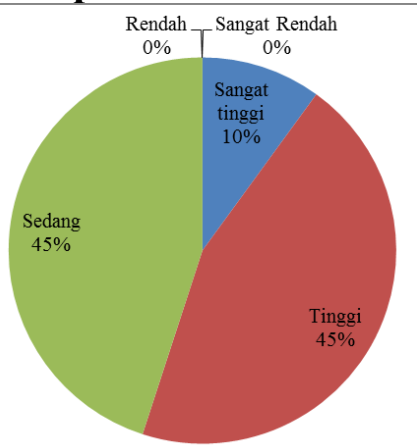

Gambar 2. Distribusi frekuensi pada indikator kesiapan fisik
Mengacu kepada Gambar 2 yang sudah disajikan sebelumnya, dapat dinyatakan bahwa jawaban responden pada indikator kesiapan fisik anak berada dalam kategori kesiapan yang tinggi. Berdasarkan analisis per butir pernyataan diketahui bahwa pada indikator kesiapan fisik jawaban responden paling banyak (55\%) yang menyatakan setuju adalah pada pernyataan "Anak menjaga pola makan sebelum mengikuti pembelajaran online". Sedangkan pada pernyataan "Anak dapat berbicara dengan lancar pada saat proses pembelajaran online" sebanyak $50 \%$ responden menjawab tidak setuju. Artinya masih terdapat permasalahan dalam kesiapan fisik dalam bentuk anak yang belum dapat berbicara dengan lancara pada saat pembelajaran online.

\section{b. Kondisi mental}

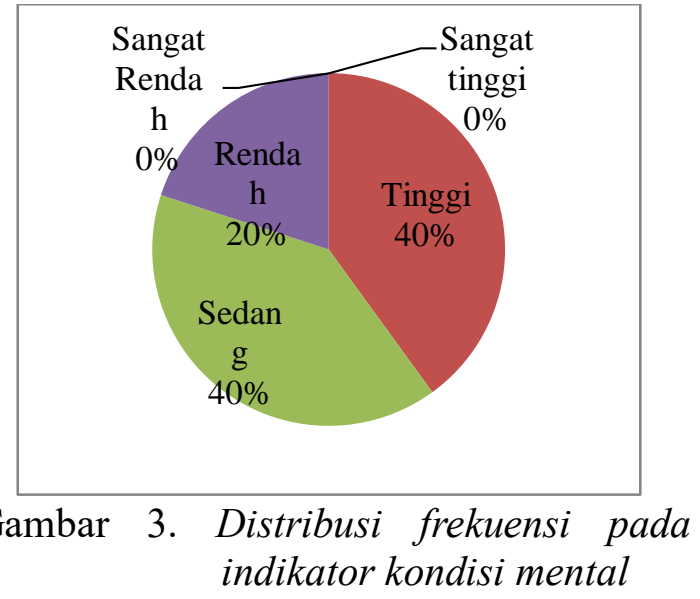

Berdasarkan Gambar 3 yang tersaji di atas, dapat dinyatakan bahwa jawaban responden pada indikator kondisi mental anak berada dalam kategori kesiapan yang sedang. Berdasarkan analisis per butir pernyataan diketahui bahwa pada indikator kondisi mental jawaban responden paling banyak (65\%) yang menyatakan tidak setuju adalah pada pernyataan "Anak mengikuti petunjuk dan perintah yang disampaikan oleh guru dalam video pembelajaran online" dan pernyataan "Anak merasa tugas-tugas 
yang diberikan sulit diselesaikan”. Artinya masih banyak terdapat permasalahan indikator kesiapan mental dalam bentuk kesiapan anak mengikuti petunjuk perintah yang disampaikan guru dan masih banyak anak yang merasa sulit dengan tugas yang diberikan.

\section{c. Kondisi emosional}

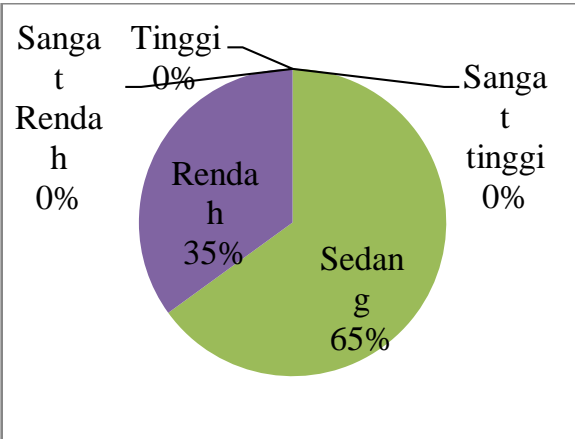

Gambar 4. Distribusi frekuensi pada indikator kondisi emosional

Berdasarkan Gambar 4 di atas, dapat dinyatakan bahwa jawaban responden pada indikator kondisi emosional anak berada dalam kategori kesiapan yang sedang. Berdasarkan analisis per butir pernyataan diketahui bahwa pada indikator kondisi mental jawaban responden paling banyak (65\%) yang menyatakan setuju adalah pada pernyataan "Anak enggan belajar jika belum diberikan materi atau video di grup whatsapp". Selain itu pada pernyataan "Anak melakukan aktivitas belajar online tanpa bantuan atau mencontoh dari jawaban yang dibuat oleh orang tua" sebanyak $60 \%$ responden menjawab sangat tidak setuju. Hal ini mengindikasikan permasalahan kondisi emosional anak yang terjadi sebagain besar meliputi anak belum dapat melakukan aktivitas belajar tanpa bantuan orang tua dan anak masih ada yang enggan belajar jika tidak ada materi/video yang diberikan guru.

\section{d. Kebutuhan terhadap materi pelajaran}

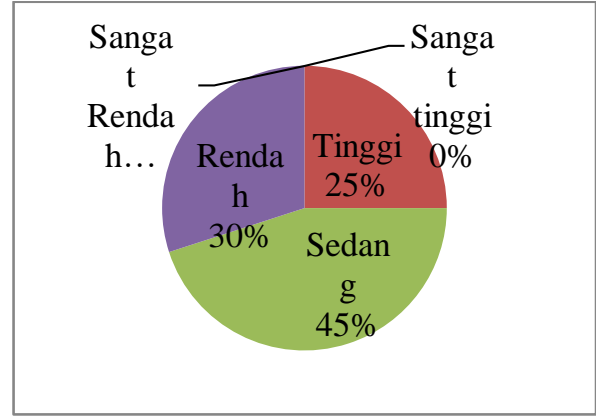

Gambar 5. Distribusi frekuensi pada indikator kebutuhan terhadap materi pelajaran

Berdasarkan Gambar 5 di atas, dapat dinyatakan bahwa jawaban responden pada indikator kebutuhan terhadap materi pada anak berada dalam kategori kesiapan yang sedang. Berdasarkan analisis per butir pernyataan diketahui bahwa pada indikator kebutuhan terhadap materi pada anak jawaban responden paling banyak (60\%) yang menyatakan tidak setuju adalah pada pernyataan "Anak mencari bahan belajar melalui internet, Koran, TV, dan lain-lain diluar materi yang disampaikan oleh guru di whatsapp". Selain itu pada pernyataan "Anak belajar dan mengikuti petunjuk guru tanpa disuruh siapapun" terdapat $50 \%$ responden yang menjawab tidak setuju. Hal ini mengindikasikan pada indikator kebutuhan terhadap materi pelajaran diketahui bahwa umumnya permasalahan anak meliputi kurangnya keinginan anak dalam mencari bahan belajar dan mencari tahu pada internet, koran, TV dan lain lain melainkan hanya fokus pada apa yang disampaikan guru dalam pembelajaran online selain itu anak juga harus disuruh oleh guru atau orang tua terlebih dahulu untuk belajar. 


\section{e. Pengetahuan atau pemahaman anak terhadap materi pelajaran}

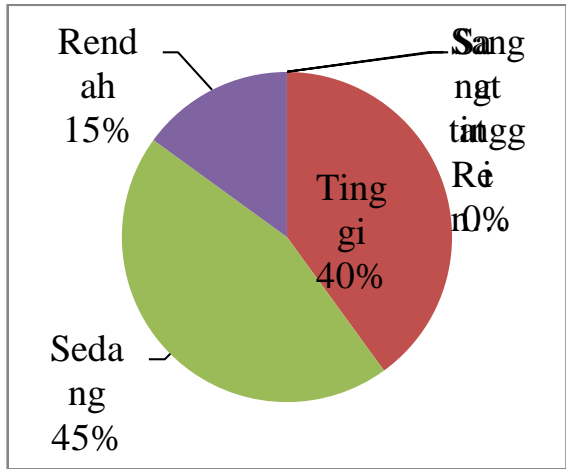

Gambar 6. Pengetahuan atau pemahaman anak terhadap materi pelajaran

Berdasarkan Gambar 6 di atas, dapat dinyatakan bahwa jawaban responden pada indikator pengetahuan atau pemahaman anak terhadap materi pelajaran pada anak berada dalam kategori kesiapan yang sedang. Berdasarkan analisis per butir pernyataan diketahui bahwa pada indikator kebutuhan terhadap materi pada anak jawaban responden paling banyak $(60 \%)$ yang menyatakan tidak setuju adalah pada pernyataan "anak memiliki nilai yang kurang memuaskan pada saat belajar online". Selain itu terdapat $50 \%$ responden menjawab setuju pada pernyataan "Anak malas jika ditanya tentang pelajaran yang sudah diberikan guru'. Hal ini mengindikasikan anak memiliki permasalahan pada indikator pengetahuan atau pemahaman anak terhadap materi pelajaran meliputi nilai yang kurang memuaskan pada pembelajaran online dan anak yang cenderung malas jika ditanya tentang pelajaran yang sudah diberikan guru.

\section{Pembahasan}

Hasil penelitian ini menunjukkan bahwa mayoritas orang tua berusia 29 35 tahun dengan usia anak 4 hingga 6 tahun. Selain itu pendidikan terakhir orang tua adalah 55\% (11 orang) S1 dan sisanya adalah tamat SMA, D3 dan paling sedikit adalah S2.

Hasil penelitian ini menunjukkan bahwa kesiapan belajar anak selama pembelajaran daring di TK Islam An-Nur Bastari Kecamatan Tampan Kota Pekanbaru sebanyak $45 \%$ berada pada kategori "sedang". Hal ini dikarenakan pada analisis setiap indikator yaitu kesiapan fisik, kondisi mental, kondisi emosional, kebutuhan terhadap materi pelajaran dan pengetahuan atau pemahaman anak terhadap materi pelajaran menunjukkan kesiapan pada kategori sedang. Dari kelima indikator, kondisi emosional memiliki nilai rata-rata paling rendah $(5,85)$ daripada indikator lainnya. Hal ini menunjukkan kesiapan belajar anak yang paling rendah adalah kesiapan emosional anak.

Hasil penelitian ini menunjukkan bahwa kesiapan belajar anak pada indikator kesiapan fisik secara umum berada pada kategori sedang. Secara umum permasalahan kesiapan fisik ditandai pada penelitian ini dengan masih terdapat permasalahan dalam kesiapan fisik dalam bentuk anak yang belum dapat berbicara dengan lancara pada saat pembelajaran online. Hal ini sesuai dengan pendapat Pratiwi (2018) yang menyatakan bahwa kesiapan anak usia dini dalam bersekolah meliputi aspek perkembangan fisik. Hal ini dikarenakan anak usia dini dalam menjalani kegiatan belajarnya tidak terlepas dari kegiatan fisik dan menggunakan energinya dalam jumlah besar karena adanya gerakangerakan motorik halus dan kasar anak yang mampu naik turun tangga, memegang pensil, memegang peralatan belajar akan mempengaruhi proses belajarnya.

Hasil penelitian ini menunjukkan bahwa kesiapan belajar anak pada indikator kesiapan mental secara umum 
berada pada kategori sedang. Secara umum permasalahan kesiapan mental pada penelitian ini ditandai dengan masih banyak terdapat permasalahan indikator kesiapan mental dalam bentuk kesiapan anak mengikuti petunjuk perintah yang disampaikan guru dan masih banyak anak yang merasa sulit dengan tugas yang diberikan. Hal ini bersesuaian dengan Rifai \& Fahmi (2017) yang mengatakan bahwa anak yang merasa siap secara mental untuk mengikuti proses kegiatan pembelalajaran akan menerima tugas yang diberikan oleh guru, terutama pada anak usia dini (PAUD) keseriusan anak dalam belajar dapat dijadikan tolak ukur dalam mental belajr anak.

Hasil penelitian ini menunjukkan bahwa kesiapan belajar anak pada indikator kesiapan emosional secara umum berada pada kategori sedang. Secara umum permasalahan kesiapan emosional pada penelitian ini ditandai dengan anak belum dapat melakukan aktivitas belajar tanpa bantuan orang tua dan anak masih ada yang enggan belajar jika tidak ada materi/video yang diberikan guru. Hasil penelitian ini sejalan dengan Wardani \& Ayriza (2020) yang menemukan bahwa menumbuhkan minat belajar anak menjadi kendala orang tua pada anak usia dini (PAUD) yang belajar di rumah selama pandemi COVID-19.

Hal ini sejalan dengan Yusuf dalam Pratiwi (2018) yang mengatakan bahwa perkembangan emosi anak usia 4-6 tahun dapat dilihat dari kesadaran bahwa keinginannya tidak selamanya dapat dipenuhi dan perlu petunjuk, pengakuan dan perasaan dihargai terutama dari orang tua. Anak yang keras kepala umumnya meniru dari orang tua atau lingkungan terdekatnya. Selanjutnya Subarto (2020) menjelaskan bahwa orang tua harus memiliki strategi dalam proses pembelajaran daring selama di rumah misalnya dalam membentuk selfregulating yang bertujuan untuk membangun perilaku mampu mengatur dan merencanakan proses belajar dirumah, misalnya dengan memberikan arahan pedoman, mendiskusikan aturan-aturan di rumah, jika anak menunjukkan emosi maka orang tua perlu menunjukkan cara mengatasi dan juga menjelaskan dampak perilaku emosional tersebut. Selain itu orang tua juga diharapkan dapat menjadi teman berdiskusi, bertanya dan menyelesaikan masalah namun tetap memberikan kesempatan anak agar mandiri mengerjakan tugas agar melatih kemandiriannya.

Hasil penelitian ini menunjukkan bahwa kesiapan belajar anak pada indikator kebutuhan terhadap materi pelajaran secara umum berada pada kategori sedang. Secara umum permasalahan kebutuhan terhadap materi pelajaran pada penelitian ini ditandai dengan kurangnya keinginan anak dalam mencari bahan belajar dan mencari tahu pada internet, koran, TV dan lain lain melainkan hanya fokus pada apa yang disampaikan guru dalam pembelajaran online selain itu anak juga harus disuruh oleh guru atau orang tua terlebih dahulu untuk belajar. Hasil penelitian ini sejalan dengan Sadikin \& Hamidah (2020) yang menemukan bahwa selama pembelajaran online di terapkan di Indonesia kendala yang dihadapi adalah memahami materi pelajaran yang diberikan secara daring selain itu bahan ajar yang diberikan dianggap tidak mudah dipahami oleh semua individu.

Hasil penelitian ini menunjukkan bahwa kesiapan belajar anak pada indikator pengetahuan atau pemahaman anak terhadap materi pelajaran secara umum berada pada kategori sedang. Secara umum permasalahan pengetahuan atau pemahaman anak terhadap materi 
pelajaran pada penelitian ini ditandai dengan nilai yang kurang memuaskan pada pembelajaran online dan anak yang cenderung malas jika ditanya tentang pelajaran yang sudah diberikan guru. Hal ini dikarenakan tidak semua proses pembelajaran dapat didampingi dengan maksimal oleh orang tua terutama saat anak malas, maka tantangan ini juga terasa berat oleh orang tua. Menurut Novianti, (2020) yang menyampaikan bahwa para ibu yang memiliki anak usia dini agar mendampingi anak dan memberi pemahaman bahwa teknologi selayaknya membawa keluarga semakin dekat satu sama lain, bukan malah menjauhkannya. Sehingga orang tua harus memainkan perannya secara bijak agar anak memiliki masa depan yang gemilang dan menciptakan hubungan yang hangat dan penuh kasih sayang dalam keluarga.

Hasil penelitian juga sejalan dengan Rigianti (2020) yang menemukan bahwa pada minggu awal kegiatan pembelajaran daring, orangtua memberikan perhatian penuh terhadap anaknya. Namun pada minggu ke dua dan seterusnya, pengawasan dari orang tua mulai berkurang. hal ini terjadi karena pada saat yang sama, orang tua siswa juga harus membagi waktu antara bekerja, mengurus rumah dan mengawasi belajar anak. Sehingga yang terjadi adalah guru mengirimkan tugas dan orang tua mengirimkan hasil pekerjaan anak. Tanpa adanya pengawasan dalam belajarnya. Lebih lanjut Rigianti (2020) menemukan bahwa para orangtua berpendapat jika tugas sudah dikirmkan kepada guru, maka selesai kegiatan belajar pada hari itu. Hal ini mengakibatkan terjadinya komunikasi searah, tanpa adanya pengawasan dalam belajar. Novianti \& Garzia (2020) juga menjelaskan bahwa peran orang tua dalam pembelajaran online juga perlu melaporkan bahwa pekerjaan anak telah dikumpulkan sehingga orang tua memang perlu mencatat dan mengawasi bahwa anak telah menyelesaikan tugas tepat waktu agar berlangsungnya pembelajaran online yang lebih baik.

\section{KESIMPULAN}

Berdasarkan hasil penelitian dapat diketahui bahwa kesiapan belajar anak selama pembelajaran daring di TK Islam An-Nur Bastari Kecamatan Tampan Kota Pekanbaru sebanyak $45 \%$ berada pada kategori "sedang". Analisis pada setiap indikator kesiapan belajar anak menunjukkan bahwa indikator kesiapan fisik sebanyak $45 \%$ berada pada kategori tinggi dan sedang, pada indikator kondisi mental sebanyak $40 \%$ berada pada kategori tinggi dan sedang, pada indikator kondisi emosional sebanyak $65 \%$ berada pada kategori sedang, pada indikator kondisi kebutuhan terhadap materi sebanyak $45 \%$ berada pada kategori sedang, pada indikator pengetahuan atau pemahaman anak terhadap materi pelajaran sebanyak $45 \%$ berada pada kategori sedang.

\section{Saran}

1. Disarankan kepada orang tua untuk meningkatkan perhatian dan pengawasan serta pendampingan dalam kebutuhan anak khususnya dalam proses belajar mengajar, baik saat pembelajaran daring maupun tidak, sehingga anak dapat menanamkan ketertarikan yang baik akan materi selama pembelajaran dan tidak teralihkan fokusnya.

2. Disarankan kepada guru untuk meningkatkan kesiapan belajar dalam indikator kebutuhan terhadap materi pelajaran. Hal ini dikarenakan pada pernyataan "anak enggan belajar jika belum diberikan materi atau video di 
grup whatsapp" banyak orang tua yang menjawab tidak setuju.

\section{DAFTAR PUSTAKA}

Abidah, A., Hidaayatullaah, H. N., Simamora, R. M., Fehabutar, D., \& Mutakinati, L. (2020). The Impact of Covid-19 to Indonesian Education and Its Relation to the Philosophy of "Merdeka Belajar." Studies in Philosophy of Science and Education, 1(1), 38-49. https://doi.org/10.46627/sipose.v1i1. 9.

Bao, W. (2020). COVID-19 and online teaching in higher education: A case study of Peking University . Human Behavior and Emerging Technologies, 2(2), 113-115. https://doi.org/10.1002/hbe2.191.

Jamal, S. (2020). Analisis Kesiapan Pembelajaran E-Learning Saat Pandemi Covid-19 Di SMK Negeri 1 Tambelangan. Jurnal Nalar Pendidikan, 8(1), 16-22.

Novianti, R. (2020). Meningkatkan pengetahuan orang tua dalam mendidik anak di era digital di Kecamatan Koto Gasib Kabupaten Siak Provinsi Riau. RIAU JOURNAL OF EMPOWERMENT, 3(3), 183190.

Novianti, R., \& Garzia, M. (2020). Parental Engagement in Children's Online Learning During COVID-19 Pandemic. Journal of Teaching and Learning in Elementary Education (Jtlee), $\quad 3(2), \quad 117$. https://doi.org/10.33578/jtlee.v3i2.78 45.

Pangestu, D., \& Rohinah. (2018). Pengaruh Kesiapan Belajar Terhadap Keaktifan Peserta Didik dalam Proses Pembelajaran AUD. Jurnal Ilmiah Tumbuh Kembang Anak Usia Dini, 3(2).
Pratiwi, W. (2018). Kesiapan anak usia dini memasuki sekolah dasar. Jurnal Manajemen Pendidikan Islam, 6(1), $1-13$.

Rifai, M., \& Fahmi. (2017). Pengelolaan kesiapan belajar anak masuk sekolah dasar. Tarbawi, 3(01), 129-143. https://doi.org/http://dx.doi.org/10.32 678/tarbawi.v3i01.1784.

Rigianti, H. A. (2020). Kendala pembelajaran daring guru sekolah dasar di Kabupaten Banjarnegara. Elementary School, 7(2), 297-302. http://repositorio.unan.edu.ni/2986/1/ 5624.pdf.

Sadikin, A., \& Hamidah, A. (2020). Pembelajaran Daring di Tengah Wabah Covid-19. BIODIK: Jurnal Ilmiah Pendidikan Biologi, 6(2), 214-224. https://doi.org/10.17509/t.v6i2.20887

Slameto. (2010). Belajar dan faktor-faktor yang Mempengaruhinya. Rineka Cipta.

Subarto. (2020). Momentum Keluarga Mengembangkan Kemampuan Belajar Peserta Didik Di Tengah Wabah Pandemi Covid-19. Adalah: Buletin Hukum dan Keadilan, 4(1), 13-18.

Wardani, A., \& Ayriza, Y. (2020). Analisis Kendala Orang Tua dalam Mendampingi Anak Belajar di Rumah Pada Masa Pandemi Covid19. Jurnal Obsesi: Jurnal Pendidikan Anak Usia Dini, 5(1), 772. https://doi.org/10.31004/obsesi.v5i1. 705. 